\title{
IMPLEMENTASI NILAI-NILAI PENDIDIKAN ISLAM MULTIKULTURAL DALAM TRADISI KENDURI NIKAH DI DESA BARUMANIS
}

\author{
IMPLEMENTATION OF MULTICULTURAL ISLAMIC EDUCATION VALUES \\ IN THE TRADITION OF THE FEAST ON MARRIAGE IN THE BARUMANIS VILLAGE
}

\author{
Dewi Purnama Sari, Sutarto
}

Institut Agama Islam Negeri (IAIN) Curup

Email: dewipurnamasari@iaincurup.ac.id

Naskah Diterima: 29 Mei 2020; Direvisi: 12 Februari 2021; Disetujui: 16 April 2021

\begin{abstract}
This paper aims to reveal the values of multicultural Islamic education which are implemented in the tradition of the feast on marriage in Barumanis village, Rejang Lebong Regency, Bengkulu Province. This research is qualitative research with a phenomenological approach. The research informants consisted of community leaders, traditional leaders, and religious leaders in Barumanis village. The data collection techniques used are passive participation observation and unstructured interviews. To check the validity of the data, the technique of extension of observations and triangulation of sources and data were used. Data analysis using the Miles and Huberman model. The results showed that the values of multicultural Islamic education that are implemented in the wedding festival tradition are, first, democratic values, which include freedom of expression, adherence to manners, and the existence of equal rights. Second, humanistic values, which include mutual respect, respect, and mutual assistance between one another in diversity. Third, pluralistic value, which includes public awareness of diversity in differences and tolerance. The values of multicultural Islamic education can become the glue of the unity of the Barumanis village community so that harmony and peace are formed in diversity.
\end{abstract}

Keywords: Values; Multicultural Islamic Education; The tradition of festivity marriage

\begin{abstract}
Abstrak
Tulisan ini bertujuan untuk mengungkapkan nilai-nilai pendidikan Islam multikultural yang diimplementasikan dalam tradisi kenduri nikah di desa Barumanis Kabupaten Rejang Lebong Provinsi Bengkulu. Penelitian ini merupakan penelitian kualitatif dengan pendekatan fenomenologis. Informan penelitian terdiri tokoh masyarakat, tokoh adat dan tokoh agama desa Barumanis. Teknik pengumpulan data yang digunakan adalah observasi passive participation dan wawancara tidak terstruktur. Untuk mengecek keabsahan data digunakan teknik perpanjangan pengamatan dan triangulasi sumber dan data. Analisis data menggunakan model Miles and Huberman. Hasil penelitian menunjukkan bahwa nilai-nilai pendidikan Islam multikultural yang diimplementasikan dalam tradisi kenduri nikah adalah pertama, nilai demokratis, yang mencakup adanya kebebasan mengemukakan pendapat, adanya kepatuhan terhadap tata krama dan adanya persamaan hak. Kedua, nilai humanistik, yang meliputi adanya sikap saling menghormati, menghargai dan saling membantu antar sesama dalam keragaman. Ketiga, nilai pluralistik, mencakup adanya kesadaran masyarakat tentang keragaman dalam perbedaan dan toleransi. Nilainilai pendidikan Islam multikultural ini mampu menjadi perekat kesatuan masyarakat desa Barumanis, sehingga terbentuk kerukunan dan kedamaian dalam keragaman.
\end{abstract}

Kata kunci: Nilai-nilai; Pendidikan Islam multikultural; Tradisi kenduri nikah 


\section{PENDAHULUAN}

Indonesia merupakan negara yang memiliki jumlah penduduk sekitar 250 juta jiwa dengan keragaman suku, bahasa, tradisi, budaya dan agama. Keragaman suku dan bahasa dibuktikan dengan adanya bermacammacam suku dan bahasa, ada suku Jawa, suku Minang, Batak, Bugis, Rejang dan sebagainya. Masing-masing suku dan bahasa tersebut memiliki tradisi dan budaya yang berbedabeda. Begitu juga dengan agama, setidaknya ada enam agama resmi yang ada di Indonesia, yaitu Islam, Kristen, Katolik, Hindu, Buddha dan Konghucu. Walau pun penuh dengan keragaman, namun tetap bersatu di bawah Negara Kesatuan Republik Indonesia, sesuai dengan semboyan "Bhinneka Tunggal Ika" berbeda-beda tetapi tatap satu.

Keragaman merupakan suatu anugerah yang sangat besar yang diberikan oleh Allah SWT kepada bangsa Indonesia. Oleh karena itu, keragaman harus disyukuri dan dikelola dengan baik agar menjadi kekuatan sosial dan potensi utama dalam membangun bangsa dan negara. Keragaman juga merupakan suatu keniscayaan dan sekaligus merupakan sunatullah yang tidak bisa dihindari. Allah SWT menciptakan manusia di muka bumi penuh dengan keragaman, ada laki-laki dan perempuan, berbangsa-bangsa dan bersukusuku agar manusia saling mengenal (QS. al Hujarat: 13). Namun, di sisi lain, keragaman dapat menjadi pemicu terjadinya konflik dan kekerasan yang dapat merusak sendi-sendi persatuan dan kesatuan bangsa, jika dalam keragaman tidak ada saling menghargai, saling menghormati dan toleransi di antara sesama. Kasus Ambon dan Poso, merupakan salah satu contoh kekerasan dan konflik horizontal yang merugikan materi, menimbulkan korban jiwa dan dapat merusak persatuan dan kesatuan bangsa (Maksum, A, 2015).

Manusia memiliki peran yang sangat penting dalam mengelola keragaman yang ada, agar menjadi sumber kekuatan dalam berbangsa dan bernegara. Banyak cara yang dapat dilakukan, agar bisa hidup berdampingan dan penuh kerukunan dalam keragaman. Di antaranya adalah mengembangkan sikap saling menghargai, saling menghormati dan toleransi antar agama, antar suku, antar tradisi, budaya dan sebagainya. Walaupun demikian, setiap daerah memiliki cara dan tradisi berbeda dalam mengelola keragaman agar mampu menjadi perekat kesatuan bangsa.

Di desa Barumnais Kecamatan Bermani Ulu Kabupaten Rejang Lebong Provinsi Bengkulu ada tradisi masyarakat yang menarik untuk di kaji. Tradisi itu bernama tradisi kenduri kawin atau walimatunnikah. Tradisi tersebut sudah ada sejak tahun 1930-an dan masih bertahan sampai saat ini (Sali, M, Komunikasi Pribadi, 2019). Secara historis, tradisi kenduri kawin yang ada di desa Barumanis sesungguhnya bukan tradisi asli masyarakat Rejang, melainkan tradisi yang berasal dari tanah Jawa dan mampu beralkuturasi dengan budaya lokal dan masyarakat sekitar yang berbeda budaya, suku, agama dan kepercayaan (Suyono, Komunikasi Pribadi, 2019).

Masyarakat desa Barumanis terdiri dari beberapa suku, ada suku Jawa sekitar 70\%, dan $30 \%$ lainnya suku lainnya seperti Batak, Bali dan suku asli yaitu suku Rejang (Profil desa Barumanis, 2018). Selain itu juga terdiri dari beberapa agama, sekitar $95 \%$ beragama Islam dan 5\% lainnya agama lain, seperti Katolik, Protestan, Hindu bahkan ada yang menganut aliran kepercayaan (Profil desa Barumanis, 2018). Walaupun berbeda suku dan agama, namun nilai-nilai pendidikan Islam multikultural dapat diimplementasikan dalam kehidupan bermasyarakat, sehingga masyarakat desa Barumanis tetap hidup rukun dan damai dalam keragaman. Hidup rukun dan damai masyarakat desa Barumanis tersebut tercermin dalam berbagai kegiatan, salah satu di antaranya adalah dalam tradisi kenduri nikah. Perbedaan suku, budaya agama dan kepercayaan, tidak menjadi penghalang bagi masyarakat untuk tetap saling tolong menolong dan bantu membantu untuk kelancaran dan kesuksesan pelaksanaan tradisi kenduri nikah masyarakat setempat. Muncul pertanyaan, nilai-nilai pendidikan Islam multikultural apa saja yang diimplementasikan dalam kenduri nikah di desa Barumanis sehingga mampu menciptakan kerukunan dalam perbedaan? Pertanyaan ini yang dibahasa secara tuntas dan mendalam dalam tulisan ini. 
KAJIAN TEORI

\section{Memahami Nilai-nilai Penididkan Islam Multikultural}

Ada tiga hal yang perlu dipahami terkait nilai-nilai pendidikan Islam multikultural, yaitu nilai, pendidikan Islam dan multikultural. Nilai adalah sesuatu yang abstrak namun diyakini kebenaran dan manfaatnya bagi seseorang atau sekelompok. Nilai dikatakan abstrak karena tidak bisa raba dan dilihat namun diyakini keberadaannya oleh seseorang atau sekelompok orang. Secara etimologi, kata nilai berasal dari bahasa Latin, valu'ere, yang berarti berdaya, diinginkan, sesuatu yang dipandang baik, berguna, bermanfaat dan paling benar menurut keyakinan seseorang atau sekelompok orang (Adisusilo, S, 2013). (Mulyana, R, 2011) mengartikan nilai sebagai sesuatu yang dijadikan tolok ukur oleh seseorang atau sekelompok orang dalam bertingkah-laku. Nilai juga berarti segala sesuatu yang diyakini dan memberikan corak dan menjadi tolok ukur dalam pemikiran seseorang (Darajat, Z, 2012). (Al Munawwar, S. A. H, 2011) menambahkan, nilai bukan hanya mempengaruhi dan menjadi tolok ukur seseorang dalam berpikir, tetapi sikap dan perilaku seseorang juga sangat dipengaruhi oleh nilai-nilai yang dianut dan diyakini. Penjelasan di atas memberikan pemahaman bahwa nilai adalah segala sesuatu yang diyakini oleh seseorang atau sekelompok orang dan kemudian mewarnai dan dijadikan tolok ukur dalam berpikir, bersikap dan bertingkahlaku.

Pendidikan secara bahasa berasal dari kata "didik" yang berarti cara atau perbuatan (Departemen Pendidikan dan Kebudayaan, 2014).Dalam bahasa Yunani, kata pendidikan diistilahkan dengan "paedagogos". Paedos berarti anak dan gogos berarti membimbing, paedagogos berarti membimbing anak (Ramayulis, 2016). Dalam bahasa Inggris diistilahkan dengan "educational" yang berarti mengembangkan atau membimbing (Manser, H \& Martin, H, 2011). Secara bahasa, pendidikan berarti cara yang dilakukan, mengembangkan atau membimbing. Dalam Islam, ada beberapa istilah yang terkait dengan pendidikan, yaitu at-tarbiyah, al ta'lim dan alta'dib. Abuddin Nata, (2016) menjelaskan, secara bahasa at-tarbiyah berarti mengembangkan apa yang ada pada diri peserta didik, baik fisik, psikis, sosial maupun spiritual. Al-Ta'lim berarti pengajaran. Shihab, M. Q, (2013) menjelaskan kata ta'lim atau yиallimu berarti mengisi benak peserta didik dengan pengetahuan atau transfer of knowledge. Al-ta'dib berarti beradab atau bersopan santun. Al-ta'dib secara bahasa bermakna pendidikan yang menekankan pada pembentukan ahklak (Abuddin Nata, 2016). Berdasarkan pengertian tersebut dapat dipahami bahwa at-tarbiyah, al ta'lim dan alta'dib memiliki makna yang sama yaitu memiliki arti yang semakna dengan pendidikan, namun memiliki penekanan yang berbeda-beda. At-tarbiyah mencakup semua aspek dan mencakup di dalamnya ada al ta'lim dan al-ta'dib. Sedangkan al ta'lim lebih menekankan pada transfer of knowledge, sementara al-ta'dib lebih menekankan pada pendidikan akhlak.

Secara terminologi, pendidikan Islam pada dasarnya upaya mengajak dan mendorong manusia untuk hidup lebih maju berdasarkan nilai-nilai kehidupan yang mulia menuju kepribadian sempurna (Fadhil al-Jamaly dalam Suripto, S, 2018). Ahmad D. Marimba (dalam Dana, M. A, 2020; Saepudin. J, 2019) mengemukakan, pendidikan Islam merupakan upaya sadar yang dilakukan oleh guru untuk membimbing peserta didik, baik jasmani maupun rohani untuk membentuk insanul kamil. Menurut Toumy Al-Syaibany (dalam Machsun, T, 2017), pendidikan Islam adalah upaya untuk mengubah tingkah laku individu atau masyarakat berdasarkan nilai-nilai Islam. Sejalan dengan itu, Ramayulis, (2016) mengemukakan bahwa, pendidikan Islam adalah proses yang dilakukan dalam rangka untuk mengembangkan potensi peserta didik berdasarkan ajaran Islam. Hal senada dikemukakan oleh Tafsir, A, (2011), pendidikan Islam pada hakikatnya merupakan upaya untuk membimbing dan mengembangkan segala potensi manusia berdasarkan nilai-nilai keislaman.

Mutikultural secara gramatikal berasal dari dua kata, multi dan cultural. Multi berarti beranekaragam atau banyak, dan cultural berarti budaya (Masgnud, 2010). Multikultural 
berarti beraneka ragam budaya (Pransiska. T, 2019). Berbeda dengan multkulturalisme, Amin Abdullah (dalam Rois, A, 2013; Wibowo A. M, 2018). menjelaskan multikulturalisme merupakan suatu paham yang menekankan adanya kesetaraan budaya lokal dengan tidak mengabaikan eksistensi dan hak-hak budaya lain. Rois, A, (2013) mengatakan, multikulturalisme merupakan suatu paham tentang keragaman budaya, dengan adanya pemahaman ini kemudian muncul sikap saling menghargai, menghormati, toleransi dan sebagainya. Jika dikaitkan dengan pendidikan, maka pendidikan multikultural merupakan suatu proses pendidikan yang menghormati dan menghargai perbedaan budaya tradisi, etnis, aliran atau agama. (Masgnud, 2010). (Baharun, H \& Awwaliyah, R, 2017), mengemukakan, pendidikan multikultural adalah pendidikan yang dilaksanakan dalam konteks keragaman budaya.

Berdasarkan beberapa konsep sebagaimana dikemukakan di atas, dapat dipahami bahwa nilai-nilai pendidikan Islam adalah sesuatu yang diyakini kebenarannya dan bermanfaat dalam membimbing seseorang atau sekelompok orang agar mendapatkan kehidupan yang lebih baik, jasmani maupun rohani berdasarkan ajaran Islam. Dalam Islam, pendidikan erat kaitannya dengan tugas kekalifah-an manusia di muka bumi dan harus dilaksanakan oleh setiap muslim. Oleh karena itu, Islam memberikan prinsip-prinsip dasar untuk dijadikan acuan dalam menjalankan pendidikan multikultural agar manusia dapat mengembangkan potensinya dan saling mengenal dalam keragaman berdasarkan ajaran Islam.

Dilihat dari sejarahnya, konsep pendidikan multikultural pertama kali muncul di Amerika Serikat sebagai solusi untuk mengatasi masalah pendidikan yang sangat diskriminatif. Pendidikan multikultural ini dirancang sedemikian rupa untuk mengakomodir berbagai perbedaan budaya, ras, suku, mengedepankan nilai kesamaan dan demokrasi. (Rois, A, 2013).H.A.R, Tilaar, (2012), mengemukakan pendidikan multikultural bukan memfokuskan pendidikan untuk kelompok, ras, suku, agama dan kultur yang dominan, melainkan pendidikan yang lebih menekankan pada pengintegrasian semua kelompok yang ada. Sejalan dengan itu, Paulo Freire (dalam

Bukhori, I, 2018) mengemukakan pendidikan multikultural adalah pendidikan yang memberikan kasamaan hak kepada semua kelompok, baik suku, ras, etnis, agama, budaya dan strata sosial. Menurut Sukardi, J. S dkk., (2019), ada beberapa nilai inti dalam pendidikan multikultural, yaitu pertama, nilai demokratis atau kebebasan berekspresi tanpa paksaan. Kedua, nilai humanisme, yaitu nilai berkaitan dengan kemanusiaan, seperti saling menolong, saling membantu, saling menghargai dan sebagainya. Ketiga, nilai pluralisme, yaitu pengakuan adanya kesetaraan, kemajemukan dan perbedaan, seperti perbedaan agama, suku, ras, budaya dan sebagainya. Hal senada juga dikemukakan oleh Suryana, Yaya \& Rusdiana H. A, (2015), nilai-nilai pendidikan mulitikultural meliputi nilai perdamaian, nilai inklusivisme, nilai toleransi, nilai humanisme dan nilai kebebasan.

Berbicara tentang pendidikan multikultural, Islam sejak lima belas abad yang lalu sudah berbicara tentang pendidikan mutikultural. Nur, M, (2019), mengatakan ada beberapa nilai-nilai yang dijadikan prinsip dasar dalam pendidikan Islam multikultural, yaitu tentang persaudaraan atau ukhuwwah, perdamaian atau shulhu, toleransi atau tasamuh, keadilan atau al-Adalah, demokrasi atau al-Hurriyah dan kesetaraan atau alSawiyah. Hal senada dikemukakan oleh Aly, A, (2011), beberapa nilai ajaran Islam yang dijadikan prinsip dasar dalam pendidikan Islam multikultural yaitu, prinsip kesetaraan, demokrasi, keadilan, kebersamaan, kedamaian, penerimaan dan pengakuan. Al Quran sebagai sumber utama pendidikan Islam ditemukan beberapa prinsip dasar pendidikan multikultural. Misalnya Q.S al Syura: 38 menjelaskan tentang prinsip dasar demokrasi, Q.S surat al Hadid: 25, membicarakan masalah kesetaraan, Q.S surat al A'raf: 181 berbicara tentang prinsip dasar keadilan, Q.S surat Ali Imran: 103 berbicara tentang persaudaraan dan Q.S surat al Kafirun: 1-6 berbicara tentang prinsip dasar toleransi. 


\section{Tradisi Kenduri Nikah}

Dalam kehidupan sehari-hari sering mendengar istilah tradisi dan budaya. Sebagian orang memberi makna yang sama antara tradisi dan budaya. Secara bahasa kata tradisi berasal dari kata traditium, yang berarti segala sesuatu yang diwariskan atau ditransmisikan dari masa lalu, dan sampai sekarang masih ada (Rodin, R, 2013). Dalam Kamus besar Bahasa Indonesia, tradisi diartikan adat istiadat yang dilaksanakan oleh masyarakat sebagai warisan dari nenek moyang. Piotr Sztompka (dalam Wojciechowska, M, 2016) mendefinisikan tradisi sebagai ide atau segala benda yang bersumber dari masa lalu dan masih ada sampai sekarang. Menurut Soerjono Soekamto (dalam Sudirman, M, 2019), tradisi yaitu semua kegiatan yang dijalankan secara berulang-ulang oleh sekelompok masyarakat. Hal senada dikemukakan oleh Coomans, M (dalam Thohiri, M. K, 2018), tradisi merupakan perilaku sekelompok masyarakat yang dilakukan secara berulang-ulang dan merupakan warisan nenek moyang. Dalam litartur Islam, ada kata yang semakna dengan tradisi adalah 'urufdan 'adat jama'iya. 'uruf yaitu kebiasaan yang dilakukan secara berulang-oleh oleh mayoritas sekelompok orang. Sedangkan 'adat jama'iyah merupakan kebiasaan yang dilakukan oleh sekelompok orang secara berulang-ulang. Bila dicermati secara sekasa, penekanan pada makna 'uruf adalah kebiasaan tersebut dilakukan oleh mayoritas sekelompok orang, namun pada tradisi hanya dilakukan oleh sekelompok orang secara berulang-ulang. Sekelompok orang belum tentu menunjukkan mayoritas sekelompok orang.

Berbeda dengan budaya, budaya dalam bahasa Sansekersta disebut buddhaya, dalam bahasa Inggris dikenal dengan istilah culture, dalam bahasa Laitin disebut colere dan dalam bahasa Belandadisebut dengan cultuur, yang berarti budi atau peradaban. Budaya juga bisa bermakna mengolah (Elly.M dkk., 2011). Kusniyati, H \& Sitanggang, N. S. P, (2016) menjelaskan, budaya merupakan semua hasil cipta dan karsa manusia atau sekelompok manusia yang diwariskan dari generasi yang satu ke generasi berikutnya. Budaya juga diartikan cara hidup sekelompok orang dan selalu berkembang, diwariskan dari generasi ke generasi berikutnya (Holilah, M, 2016). Pembentukan dan perkembangan budaya dipengaruhi oleh banyak unsur, diantaranya adalah sistem agama, politik, adat istiadat, bangunan, seni dan Bahasa (Suhendroyono, S \& Novitasari, R, 2016). Hal ini lah yang menyebabkan budaya antara daerah yang satu dengan lainnya berbeda-beda, karena dibentuk dan dikembangkan oleh unsur yang berbedabeda.

Berdasarkan beberapa definisi tradisi atau kebiasaan dan budaya sebagaimana dikemukakan di atas, dapat dipahami bahwa tradisi merupakan segala sesuatu yang dilakukan oleh sekelompok orang secara berulang-ulang dan diwariskan secara turun temurun. Sedangkan budaya adalah cara hidup, hasil cipta, karya dan karsa sekelompok orang. Tradisi dan budaya saling berkaitan. Budaya tanpa dilakukan secara berulang-ulang, lama kelamaan budaya tersebut akan punah. Sedangkan tradisi yang dilakukan oleh sekelompok orang pada umumnya adalah budaya sekelompok masyarakat itu sendiri.

Kenduri kawin atau kenduri perkawinan atau di sebagian daerah mengistilahkan dengan walimatulu'rs atau walimatunnikah (Pulungan, K. S, 2019). Dalam Kamus Besar Bahasa Indonesia kenduri berarti jamuan makan guna memperingati peristiwa penting atau meminta berkah (Departemen Pendidikan dan Kebudayaan, 2014). Masyarakat Jawa sering menyebut kenduri dengan istilah kenduren atau selamatan, atau bancaan makan (Siswayanti, N, 2018). Secara historis, kenduri sesungguhnya sudah ada sejak zaman dulu sebelum masuknya Islam ke nusantara. Kenduri nikah atau kenduri perkawinan atau walimatulu'rs pada hakikatnya merupakan jamuan makan sebagai ungkapan rasa syukur kepada Yang Maha Kuasa atas nikmat dan berkah yang di berikan. Kenduri nikah juga dimaksudkan untuk memberitahu kepada khalayak pasangan tersebut sudah resmi menjadi suami istri. Di samping itu juga ada nilai kemanusiaan, yaitu dijadikan sebagai salah satu media untuk bersilaturahmi di antara sesama. 


\section{Kajian Penelitian Terdahulu}

Penelitian terkait dengan nilai-nilai pendidikan Islam multikultural sudah ada dalam penelitian terdahulu, namun memiliki fokus kajian yang berbeda-beda. Penelitian yang dilakukan oleh Rofiq, A \& Muqfy, H, (2019), yang menekankan pentingnya pendidikan Islam multikultural untuk menjaga persatuan bangsa. Aly, A, (2017) mengemukakan, hasil penelitiannya menunjukkan bahwa nilai-nilai mulikultural seperti keadilan, demokrasi, mengakui adanya perbedaan dan kesetaraan sesungguhnya sudah lama dilaksanakan dalam pendidikan di Pondok Pesantren Modern Islam Assalaam. Ahsantudhoni, A, (2019) menawarkan beberapa konsep pengembangan kurikulum Pendidikan Agama Islam multikultural. Pransiska, T. (2020) menawarkan model pendidikan multikultural ramah anak di panti asuhan. Lebih lanjut Ahsantudhoni, A, (2019) menjelaskan bahwa salah satu aspek penting yang harus dimuat dalam kurikulum Pendidikan Agama Islam adalah tentang toleransi, keadilan dan kesetaraan.

Penelitian lain juga dikemukakan oleh Alam, M, (2018) yang mengemukakan beberapa ajaran Islam yang berbicara tentang prinsip dasar pendidikan multikultural, di antaranya adalah tentang persaudaraan, saling mengasihi, saling mengenal, saling menghormati, saling berlomba dalam kebaikan dan sebagainya. Menurut Supriadi, S, (2017), ada tantangan besar' dalam melaksanakan pendidikan Islam multikultural, di antaranya adalah adanya sikap fanatisme dan kurangnya pemahaman dan simpati kelompok-kelompok tertentu tentang pendidikan Islam multikultural. Walau pun demikian, hal ini dapat diatasi dengan cara pendidikan Islam multikultural harus dimasukkan ke dalam kurikulum Pendidikan Agama Islam dan harus ada upaya dari para tokoh agama untuk memberikan pemahaman kepada kelompok tertentu tentang pendidikan Islam multikultural.

Beberapa penelitian terdahulu kebanyakan hanya berbentuk kajian library resesrch dengan menawarkan beberapa konsep pendidikan Islam mulikultural secara teoritis dan mengkaji tentang prinsip-prinsip dasar pendidikan Islam multikultural yang terdapat di dalam al Quran. Hanya satu yang peneliti temukan, penelitian yang mengkaji secara empiris, namun hanya mengkaji pendidikan Islam multikultural di pondok pesantren yang memiliki kultur, agama dan keyakinan yang sama atau homogen. Penelitian yang dilakukan ini akan memfokuskan pada implementasi pendidikan Islam multikultural pada masyarakat heterogen. Masyarakat yang memiliki perbedaan suku, budaya, agama dan kepercayaan.

\section{METODOLOGI}

Penelitian ini merupakan penelitian kualitatif dengan pendekatan fenomenologi. Penelitian kualitatif merupakan jenis penelitian yang berupaya membangun pandangan terhadap suatu fenomena yang diamati atau terhadap ucapan lisan orang yang menjadi objek penelitian secara mendalam dan rinci berlatar alamiah, kemudian didiskripsikan dengan menggunakan kata-kata (Moleong, 2014). Pendekatan fenomeoligi merupakan salah satu pendekatan dalam penelitian kualitatif yang mengungkapkan, merefleksikan dan melihat esensi dari pengalaman atau yang dibicarakan seseorang atau beberapa orang yang terkait dengan masalah penelitian (Kahija, Y. L, 2017). Dalam konteks ini, pendekatan fenomenologi digunakan untuk mengungkapkan, merefleksikan dan menemukan esensi dari pengalaman atau yang dibicarakan oleh informan penelitian terkait implementasi pendidikan Islam multikultural dalam tradisi kenduri kawin di desa Barumanis Kecamatan Bermani Ulu Kabupaten Rejang Lebong Provinsi Bengkulu. Kemudian dideskripsikan menggunakan kata-kata secara tertulis sehingga bisa dibaca dan dipahami oleh pembaca. Penelitian ini dilakukan pada tahun 2019 dibiayai DIPA IAIN Curup tahun angkatan 2019.

Informan dalam penelitian ini terdiri dari tokoh masyarakat, pemuka agama dan pemuka adat yang mengerti dan memahami tradisi kenduri di desa Barumanis. Informan penelitian ditetapkan dengan menggunakan teknik purposif sampling, yaitu teknik penentuan informan penelitian berdasarkan pertimbangan tertentu (Sugiono, 2018). Dasar 
pertimbangan yang peneliti gunakan adalah informan yang paling mengerti dan memahami masalah penelitian. Teknik pengumpulan data yang digunakan adalah observasi passive particioation dan wawancara tidak terstruktur. Sugiono, (2018) menjelaskan, observasi passive particioation adalah teknik pengumpulan data di mana peneliti datang ke tempat informan melakukan kegiatan, peneliti hanya mengamati dan tidak ikut serta melakukan kegiatan yang dilakukan oleh informan penelitian. Wawancara tidak terstruktur adalah salah satu teknik pengumpulan data di mana peneliti menggunakan pedoman wawancara, namun hanya berupa garis-garis besar yang terkait dengan masalah penelitian (Nazir, Moh., 2015). Wawancara dilakukan dengan tokoh masyarakat, pemuka agama, pemuka adat, aparat desan dan tokoh pemuda desa Barumanis Kabupaten Rejang Lebong Provinsi Bengkulu.

Untuk mendapatkan data yang kredibel, peneliti menggunakan teknik perpanjangan pengamatan dan triangulasi. Perpanjangan pengamatan dilakukan jika data yang diperoleh dari observasi sebelumnya dianggap belum menjawab masalah penelitian, maka peneliti kembali ke lokasi penelitian untuk melakukan observasi kembali (Nazir, Moh., 2015). Triangulasi merupakan teknik pengujian kredibilitas data yang dilakukan dengan pengecekan data melalui berbagai teknik pengumpulan dan sumber data (Sugiono, 2018). Triangulasi yang digunakan dalam penelitian ini adalah triangulasi teknik dan triangulasi sumber. Triangulasi teknik pada dasarnya adalah teknik pengecekan kredibilitas data penelitian dengan menggunakan beberapa teknik pengumpulan data. Dalam penelitian ini teknik pengumpulan data yang digunakan observasi passive particioation dan wawancara tidak terstruktur. Triangulasi sumber merupakan teknik pengujian kredibilitas data dengan cara mengecek data yang diperoleh melalui beberapa sumber (Sugiono, 2018).

Teknik analisis data yang digunakan adalah teknik analisis data model Miles and Huberman. Teknik analisis data model ini terdiri dari tiga langkah, yaitu: Pertama, reduksi data adalah memilih, merangkum dan mengelompokkan data yang diperoleh sesuai dengan masalah penelitian dan membuang data yang tidak diperlukan. Kedua, penyajian data, yaitu menyajikan data dalam bentuk tek naratif. Ketiga, penarikan kesimpulan.

\section{HASIL DAN PEMBAHASAN Setting Sosial Budaya Masyarakat Desa Barumanis}

Desa Barumanis terletak di kaki Bukit Daun di Kecamatan Bermani Ulu Kabupaten Rejang Lebong Provinsi Bengkulu. Desa tersebut berada pada $03^{\circ} 2455,78^{\prime \prime}$ LS dan $102^{\circ} 13.32$ " BT dengan ketinggian +/- 1.200 meter di atas permukaan laut. Sebagian besar atau sekitar 97\% desa Barumanis merupakan daerah perkebunan, dengan komoditas utamanya adalah kopi, karet dan durian. Sementara 3\% lainnya adalah lahan persawahan dan kolam ikan(Profil Desa barumanis, 2018).

Pada awalnya, desa Barumanis bernama desa air manis dan merupakan area perkebunan teh yang dibangun oleh kolonoal Belanda pada tahun 1927. Pada masa kolonial Belanda, orang-orang Jawa didatangkan ke desa Barumanis untuk bekerja di perkebunan teh dengan sistem kontrak. Para pekerja dari tanah Jawa tinggal di bedengan milik perusahaan di pusat perkebunan teh yang terletak di Kampung Melayu. Bertahun-tahun masyarakat jawa menjalani kehidupan sebagai buruh teh di desa tersebut sampai kemerdekaan Indonesai diproklamasikan (Sali, M, Komunikasi Pribadi, 2019).

Setelah penjajah Belanda meninggalkan Indonesia, sebagian besar masyarakat jawa tetap tinggal di desa Barumanis dan diizinkan membuka lahan perkebunan teh sebagai lahan usaha masyarakat. Seiring dengan pergeseran waktu, masyarakat desa Barumnais mengalih fungsikan perkebunan teh menjadi perkebunan kopi, karet, durian, dijadikan lahan persawahan dan kolam ikan seperti sekarang ini(Bastari, Komunikasi Pribadi, 2019).

Secara demografis, jumlah penduduk sekitar 2.171 jiwa dengan 758 Kepala Keluarga. Jumlah pendudukan laki-laki sekitar 1.110 jiwa dan perempuan sekitar 1.059 jiwa. Sebagian besar mata pencaharian penduduk 
adalah petani, ada sebagai pedagang, peternak, Pegawai Negeri Sipil (PNS), karyawan dan buruh. Dilihat dari struktur masyarakatnya, desa Barumanis termasuk desa multikultural, karena masyarakat yang tinggal di desa tersebut terdiri bermacam suku, budaya, agama dan keyakinan. Dari segi suku dan budaya masyarakat desa Barumanis,70\% berasal dari suku Jawa, 25\% Suku Rejang, dan 5\% dari suku Minang, Batak, Lembak, dan lainnya. Dari segi agama dan keyakinan, masyarakat desa Barumanis mayoritas atau sekitar 95\% beragama Islam, 5\% lainnya beragama Katolik, Hindu dan Penganut Kepercayaan Sapto Darmo(Profil desa Barumanis, 2018). Walaupun demikian, masyarakat desa Barumanis dapat hidup rukun, damai, saling membantu, saling bekerja sama dan saling berdampingan antar suku, budaya dan pemeluk kepercayaan yang ada. Berdasarkan catatan yang ada, di desa Barumanis belum pernah terjadi konflik yang disebabkan oleh perbedaan suku, budaya, agama dan keyakinan.

Kehidupan sosial masyarakat desa Barumanis kebanyakan masih bersifat tradisional, baik dalam interaksi sosial maupun dalam pengembangan perekonomian(Sali, M, Komunikasi Pribadi, 2019). Dalam melakukan interaksi sosial, masyarakat di desa Barumanis tidak ada batas-batas tertentu, antara satu dengan lainnya saling mengenal(Warsito, Komunikasi Pribadi, 2019).Kerja sama antar anggota masyarakat masih tinggi, pola interaksi bersifat kekeluargaan(Suryono, Komunikasi Pribadi, 2019).Interaksi sistem kerja di masyarakat didasari oleh semangat gotong royong. Keakraban antar sesama anggota masyarakat sangat bagus. Pembagian tugas dalam kehidupan masyarakat seperti ketua panitia kenduri walimah, memimpin doa dan tahlilan didasarkan pada tingkat usia bukan keahlian(Bastari, Komunikasi Pribadi, 2019). Begitu juga halnya dengan pengembangan perekonomian kebanyakan masih dilakukan secara tradisional. Hal ini terlihat dalam pengolahan hasil perkebunan serti kopi, gula aren dan pertanian seperti padi serta sayursauran kebanyakan diolah secara tradisional (Sali, M, Komunikasi Pribadi, 2019).
Tradisi keagamaan masih dipegangteguh oleh sebagian besar masyarakat desa Barumanis. Tradisi tersebut diwariskan secara turun temurun dari generasi yang satu ke generasi berikutnya. Di antara beberapa tradisi keagamaan yang masih tetap dilaksanakan oleh masyarakat desa Barumanis adalah tradisi selamatan, tradisi kenduri walimah, tradisi sedekah bumi, tradisi suroan, tradisi ziarah kubur, tradisi keduri arwah dan tradisi selamatan kelahiran bayi. Tradisi selamatan dilakukan ketika mendapatkan nikmat tertentu, seperti menempati rumah baru, mendapatkan pekerjaan dan sebagainya. Tradisi kenduri walimah adalah selamatan yang dilakukan oleh masyarakat setempat setelah melangsungkan pernikahan. Tradisi sedekah bumi biasanya dilakukan setahun sekali setelah panen raya. Tradisi suroan adalah selamatan yang dilakukan untuk memperingati malam satu suro. Tradisi kenduri arwah dilakukan pada hari-hari tertentu kematian, seperti tiga hari, tujuh hari, seratus hari dan seribu hari. Sedangkan tradisi selamatan kelahiran dilakukan apabila ada anggota keluarga yang baru melahiran(Sali, M, Komunikasi Pribadi, 2019).

Tradisi kenduri kawin atau walimatunnikah merupakan salah satu tradisi di desa Barumani Kecamatan Bermani Ulu Kabupaten Rejang Lebong Provinsi Bengkulu yang masih ada sampai sekarag. Tradisi ini sudah dilaksanakan oleh masyarakat sejak berpuluh-puluh tahun yang lalu (Suryono, Komunikasi Pribadi, 2019). Kenduri nikah biasanya dilaksanakan sesaat atau beberapa hari setelah prosesi pernikahan. Kenduri nikah dilaksanakan dengan tujuan sebagai ungkapan rasa syukur kepada Yang Maha Kuasa atas segala nikmat dan karunia yang telah diberikan, sehingga acara prosesi pernikahan berjalan dengan lancar. Pada acara kenduri nikah juga dipanjatkan doa agar rumah tangga kedua mempelai bahagia dan langgeng sampai ke anak cucu. Selain itu. Kenduri nikah bertujuan untuk memberitahu kepada khalayak, bahwa pasangan tersebut sudah resmi menjadi suami istri. Selain itu, kenduri nikah juga dijadikan sarana untuk menjalin silaturahmi dengan kerabat, saudara dan masyarakat sekitar (Sali, M, Komunikasi Pribadi, 2019). 
Sebelum dilaksanakan acara kenduri nikah, ada beberapa rangkaian kegiatan yang dilakukan oleh masyarakat yang akan melaksanakan acara tersebut. Rangkaian kegiatan itu di antaranya adalah hantaran, rapat pembentukan panitia, mendirikan tenda atau tarub, masak memasak makanan dan prosesi akad nikah. Dalam kegiatan tersebut, kebiasaan ahli rumah yang akan melaksanakan hajatan, mengundang sanak saudara, famili dan seluruh masyarakat sekitar dengan tidak membedakan suku, budaya, agama dan kepercayaan (Suyono, Komunikasi Pribadi, 2019). Salah seorang tokoh masyarakat setempat membenarkan hal tersebut, namun adakalanya orang yang beda agama dan keyakinan ada yang menghadiri dan ada yang tidak, khususnya pada acara lamaran dan prosesi pernikahan, tetapi kebanyakan menghadiri acara kenduri nikah (Warsito, Komunikasi Pribadi, 2019).

\section{Implementasi Nilai-Nilai Pendidikan Islam Multkultural dalam Tradisi Kenduri Nikah}

Berdasarkan hasil penelitian, ada beberapa nilai-nilai pendidikan Islam multikultural yang diimplementasikan dalam tradisi kenduri nikah, yaitu :

\section{Nilai Demokrasi}

Pemahaman terhadap demokrasi dapat dilakukan dengan dua cara yaitu secara normatif dan secara empirik. Pemahaman secara normatif, demokrasi diartikan sebagai sesuatu yang dianggap ideal yang dilaksanakan oleh suatu negara berdasarkan konstitusi. Misalnya, di Indonesia sistem demokrasi diatur dalam Undang-undang dasar 1945. Oleh karena itu untuk memahami sistem demokrasi yang ada di Indonesia secara normatif, maka harus mengungkapkannya berdasarkan Undang-undang dan ketentuan lain yang berlaku di Indonesia. Pemahaman secara empiris, adalah demokrasi yang dilaksanakan dalam politik praktis. Menurut Plano (dalam Suacana, I. W. G, 2015), nilai-nilai demokrasi, baik secara normatif maupun secara empiris sesungguhnya banyak terdapat dalam tradisi dan budaya masyarakat yang sudah membentuk pola tingkah laku dalam kehidupan bermasyarakat. Koentjaraningrat (dalam Suacana, I. W. G, 2015) menjelaskan, untuk mengetahui nilai-nilai demokrasi dalam kehidupan masyarakat, dapat dilihat dari sistem religi dan upacara keagamaan, sistem pengetahuan, kesenian dan bahasa, mata pencaharian dan sistem teknologi dan paralatan yang digunakan oleh masyarakat.

Tradisi kenduri nikah yang dilaksanakan oleh masyarakat desa Barumanis erat kaitannya dengan sistem religi masyarakat setempat. Pelaksanaan tradisi kenduri nikah diiringi dengan beberapa kegiatan keagamaan, seperti membaca al Quran, marhaban, berdoa bersama dan dilaksanakan jauman makan bersama (Saring, Komunikasi Pribadi, 2019). Ada beberapa nilai demokrasi yang terdapat dalam tradisi kenduri nikah, di antaranya; Pertama, adanya kebebasan berkumpul dan mengemukakan pendapat. Kebebasan berkumpul terlihat ketika masyarakat yang akan melaksanakan hajatan kenduri nikah mengundang sanak saudara dan masyarakat untuk menghadiri acara hantaran, rapat panitia, prosesi akad nikah, mendirikan tarub atau tenda, masak bersamaan dan mengadakan jamuan pernikahan. Dalam rapat pembentukan panitia, masyarakat diberi kebebasan untuk menyampaikan pendapatnya untuk kebaikan dan kelancaran acara kenduri nikah (Bastari, Komunikasi Pribadi, 2019).

Kedua, adanya kepatuhan terhadap tata krama. Tata krama merupakan sopan santun dalam bertindak. Tata krama juga bermakna aturan yang baik, baik menurut agama dan keyakinan serta baik menurut tradisi. Tradisi kenduri nikah di desa Barumanis dilaksanakan berdasarkan tara krama yang belaku. Ada beberapa ketentuan yang harus dipatuhi oleh masyarakat dalam melaksanakan kenduri nikah, misalnya dalam melaksanakan kenduri walimah tidak boleh ada permainan judi, tidak boleh minum-minuman keras, dilaksanakan sesuai dengan ketentuan agama dan tradisi yang berlaku (Saring, Komunikasi Pribadi, 2019).

Ketiga, adanya semangat kerja sama. Semangat kerja sama dalam tradisi keduri nikah terlihat mulai sebelum sampai berakhirnya acara kenduri nikah. Sebelum acara kenduri nikah, masyarakat yang diundang untuk menghadiri acara hantaran, rapat panitia, acara akad nikah dan keduri 
nikah. Selain itu, masyarakat sekitar saling bantu membantu dalam memasak makanan. Ada yang membawa beras, sayuran-sayuran, ayam dan sebagainya (Tumisem, Komunikasi Pribadi, 2019). Sebagian masyarakat juga saling bekerja sama dan saling membantu dalam mendirikan tarub atau tenda. Kerja sama dan saling membantu tersebut didasari oleh semangat kekeluargaan, bukan atas dasar paksaan. Masyarakat menyadari, setiap manusia pasti memerlukan bantuan orang lain. "Hari ini orang lain yang mempunyai hajatan untuk melaksanakan acara kenduri nikah, besok atau lusa mungkin kita yang akan melaksanakan hajatan. Jika kita tidak acuh terhadap kepentingan orang lain, maka orang lain akan tidak peduli terhadap kepentingan kita (Suyono, Komunikasi Pribadi, 2019)". Kesadaran masyarakat inilah yang menjadi salah satu faktor penyebab kerja sama dan kebersamaan pada masyarakat desa khususnya di desa Barumanis masih tetap lestari sampai sekarang.

Keempat, adanya kesetaraan dan persamaan hak. Kesetaraan dan persamaan hak merupakan salah satu indikator jalannya prinsip-prinsip demokrasi dalam suatu negara maupun masyarakat, termasuk dalam pelaksanaan acara kenduri nikah di desa Barumanis. Semua warga yang ada di sekitar tempat acara kenduri nikah, bahkan famili, keluarga, kerabat, teman dan sahabat dari desa lain tanpa memperhatikan status ekonomi dan sosial diundang untuk menghadiri acara kenduri nikah (Sali, M, Komunikasi Pribadi, 2019). Selain itu, warga desa Barumanis mempunyai hak yang sama dalam acara kenduri nikah, tanpa membedakan suku, bahasa, asal daerah termasuk agama dan kepercayaan. Warga punya hak untuk melaksanakan acara kenduri nikah, punya hak untuk dibantu, ditolong, dihormat dan sebagainya (Warsito, Komunikasi Pribadi, 2019).

Kelima, adanya rotasi kepemimpinan. Dalam acara kenduri walimah juga ada rotasi kepemimpinan. Rotasi kepemimpinan ini terlihat dalam kepanitiaan kenduri nikah. Kepanitiaan dalam acara kenduri walimah di desa Barumanis, biasanya dipilih secara aklamasi berdasarkan kesepakatan masyarakat dalam rapat panitia dan berakhir setelah acara kenduri nikah selesai. Panitia dibubarkan pada acara pembongkaran tarub atau tenda. Ketika ada warga yang akan melaksanakan kenduri nikah, maka kepanitiaan tersebut dibentuk kembali. Struktur kepanitiaan tersebut terdiri dari Ketua Panitia, Wakil Ketua, Sekretaris, Seksi Acara, Seksi Masak Memasak, Seksi Hidangan, Seksi, Jamuan, Seksi Tamu, Seksi Keamanan dan Seksi Perparkiran (Bastari, Komunikasi Pribadi, 2019). Di lihat dari aspek rotasi kepemimpinan kepanitiaan, maka dalam acara kenduri nikah ada nilai-nilai demokrasi. Kepanitiaan dipilih secara aklamasi dan kesepakatan bersama. Warga masyarakat yang terpilih, dengan suka rela melaksanakan tugas kepanitiaan sampai acara selesai.

Keenam, adanya toleransi dalam perbedaan. Masyarakat desa Barumanis merupakan masyarakat multiktural, yang terdiri dari beberapa suku, budaya, agama dan aliran kepercayaan. Keragaman tersebut, bukan menjadi hambatan untuk saling toleransi antar sesama. Toleransi antar sesama, terlihat dalam pelaksanaan acara kenduri nikah. Hal ini terlihat dengan adanya sikap saling menghormat dan menghargai antar kelompok dan antar individu yang melaksanakan acara kenduri nikah. Walaupun berbeda suku, budaya, daerah asal, agama dan kepercayaan, kebanyakan masyarakat sekitar menghadiri undangan dalam acara kenduri nikah yang diselenggarakan oleh warga desa Barumanis (Suyono, Komunikasi Pribadi, 2019). Kehadiran masyarakat terebut merupakan salah satu bentuk nyata adanya sikap toleransi antar sesama.

Berdasarkan hasil penelitian sebagaimana dikemukakan di atas, menunjukkan bahwa dalam pelaksanaan tradisi kenduri nikah di desa Barumnais, terdapat beberapa nilai demokrasi sebagai salah satu ciri adanya implementasi nilai-nilai pendidikan Islam multikultural. Nilai demokrasi tersebut di antaranya adalah adanya jaminan kebebasan untuk berkumpul, adanya kepatuhan masyarakat terhadap tata kerama, adanya kerja sama, adanya kesetaraan dan persamaan, adanya rotasi kepemimpinan kepanitiaan, dan adanya toleransi dalam perbedaan. Nilai-nilai demokrasi tersebut sesungguhnya sudah ada 
dan sudah diterapkan oleh masyarakat dalam kehidupan sehari-hari. Hal ini sejalan penjelasan Suacana, I. W. G, (2015), bahwa tradisi dan budaya masyarakat serat dengan nilai-nilai demokrasi dan diwariskan secara turun temurun dari generasi yang satu ke generasi berikutnya. Zuhro, 2009; Gaffat, 2004; Sorensen, 2003; Macris dan Brown, 1977, (dalam Suacana, I. W. G, 2015) juga menjelaskan indikator yang digunakan untuk mengukur nilai-nilai demokrasi yang berkembang dalam kehidupan masyarakat, di antaranya adalah adanya kebebasan berkumpul dan mengeluarkan pendapat, kepatuhan terhadap tata kerama, adanya semangat kerja sama, adanya kesetaraan dan penghargaan hak, adanya rotasi kepemimpinan dan adanya toleransi dalam perbedaan.

Menurut Prasisko, Y. G, (2019), di dalam adat istiadat, budaya tradisi, ritus, dan pengetahuan masyarakat memiliki nilai-nilai demokrasi yang punya andil sangat besar dalam masyarakat multikultural. Pembentukan sikap dan perilaku demokratis dalam setiap individu, dipengaruhi oleh banyak faktor, di antaranya adalah pola asuh orang tua, lingkungan keluarga, lingkungan pendidikan dan lingkungan masyarakat. Setiawan, A \& Sulistiani, I. R, (2019), nilai-nilai budaya lokal di samping memiliki nilai-nilai pendidikan, juga memiliki nilai yang penting dalam membangun karakter demokratis peserta didik. Selain itu, lingkungan pendidikan juga memiliki peran yang sangat penting dalam mengembangkan pemahaman, sikap dan perilaku demokrasi. Oleh karena itu, dalam dunia pendidikan, perlu dikembangkan kebebasan berpendapat dan berkarya, adanya persamaan, adanya penghormatan terhadap martabat individu (Irawan, I \& Hermawan, D, 2019).

\section{Nilai Humanistik}

Islam dikenal sebagai agama yang sangat humanis, bahkan tauhid sebagai dimensi transendental tidak bisa dipisahkan dengan dimensi sosial. Kesempurnaan ketauhidan seseorang sangat ditentukan oleh kesempurnaan kesolehan sosial. Banyak ditemukan ayat dalam al Quran yang menyandingkan antara iman dan amal soleh, misalnya Q.S surat al Asr:1-3, Q.S surat an
Nisa': 4, dan sebagainya. Salah satu bentuk amal soleh itu adalah berbuat baik terhadap sesama manusia, seperti saling menghormati, saling menghargai, saling tolong menolong, menjaga perdamaian, menjaga persaudaraan, toleransi, berjiwa rahmatan lil 'alamin dan sebagainya. Hal ini menunjukkan bahwa Islam juga mengajarkan tentang nilai-nilai humanistik. Nilai-nilai humanistik dalam Islam merupakan humanistik teosentris yang bersumber dari al Quran dan Sunnah. Humanistik dalam Islam tidak boleh merendahkan manusia, dan tidak boleh juga mendewakan manusia.

Nilai-nilai humanistik teosentris sangat diperlukan dalam masyarakat multikultural agar tercipta kedamaian dan ketentraman. Nilai-nilai humanistik ini bukan hanya ada dalam tataran konsep, tetapi sudah diimplementasikan dalam kehidupan seharihari pada kehidupan masyarakat, termasuk dalam melaksanakan suatu tradisi. Di desa Barumanis, nilai-nilai humanistik ini telah diimplementasikan oleh masyarakat dalam melaksanakan suatu tradisi, salah satu di antaranya adalah dalam melaksanakan tradisi kenduri nikah. Hasil penelitian menunjukkan ada beberapa nilai humanistik yang diimplementasikan dalam tradisi kenduri walimah, yaitu : pertama, toleransi. Toleransi pada hakikatnya adalah sikap saling menghormati, menghargai dan tidak saling mengganggu antar sesama dan antar kelompok yang berbeda suku, budaya, bahasa, agama dan keyakinan. Hal ini sesuai dengan ungkapan yang disampaikan oleh salah seorang tokoh agama desa Barumanis yang menyatakan bahwa "walaupun berbeda agama dan budaya, masyarakat sangat toleran. Dalam kenduri walimah ini, sangat terlihat sekali sikap toleransi masyarakat, walaupun yang punya hajatan kenduri walimah tersebut berbeda suku, budaya, agama atau kepercayaan, masyarakat tetap menghormati dan tidak saling mengganggu (Saring, 2019)". Senada dengan itu Sali, M, (Komunikasi Pribadi, 2019) juga mengatakan "sikap toleransi itu juga diwujudkan dalam bentuk sikap menghadiri undangan kenduri nikah (Sumarno, Komunikasi Pribadi, 2019). 
Kedua, adanya sikap tolong menolong dan saling membantu. Dalam pelaksanaan tradisi kenduri nikah di desa Barumanis tercermin adanya sikap tolong-menolong dan saling membantu. Sikap itu terlihat ketika anggota masyarakat bergotong royong dalam memasak makanan, mendirikan dan membongkar tarub atau tenda. Bahkan sebagian masyarakat ada yang membawa beras, ayam dan sayuran untuk dimasak pada jamuan dalam acara kenduri nikah (Tumisem, Komunikasi Pribadi, 2019). Sikap tolongmenolong dan saling membantu ketika ada hajatan ini, seperti kenduri nikah, sudah ada sejak lama dan masih berlangsung sampai sekarang. Sikap tolong-menolong dan membantu ini tidak dibatasi oleh suku, budaya, agama atau kepercayaan, yang penting adalah yang mengadakan acara kenduri nikah anggota masyarakat desa Barumanis.

Nilai-nilai humanistik yang diimplementasikan oleh masyarakat desa Barumanis dalam tradisi kenduri nikah adalah sikap toleransi, tolong menolong dan saling membantu. Kedua sikap ini sangat penting dan diperlukan dalam menciptakan keharmonisan dalam masyarakat multikultural (Pettalongi, S. S, 2013). Kurangnya sikap humanis terhadap sesama, sering kali menjadi faktor utama yang menyebabkan terjadinya konflik antar sesama (Azizah, L \& Azhar, P, 2016). Dalam penelitian lain juga dijelaskan, sikap humanis bukan hanya dapat meredam terjadinya konflik, tetapi juga mampu meningkatkan self esteem seseorang(Amalia, R, 2016), dapat membangun karakter religius (Arifin, Z, 2011), dapat mengembangkan budaya toleransi antar sesama (Malla, H. A. B, 2017), dan dapat dijadikan salah satu pendekatan dalam pembelajaran multikultural (Jamhuri, M, 2018). Dengan adanya sikap humanis ini, individu merasa dihormati, dihargai, diperlakukan secara baik dan pada gilirannya akan melahirkan sikap rukun antar sesama.

\section{Nilai Pluralistik}

Pluralisme merupakan pengakuan atau kesadaran adanya kemajemukan dan keragaman yang harus diterima. Seseorang yang menyadari adanya kemajemukan dan keragaman akan ditunjukkan dalam sikap saling menghargai, menghormati dan memelihara kedamaian antar sesama. Perkembangan pluralisme ini diyakini akan mampu memberikan kedamaian dan dapat menekan konflik yang mengatasnamakan suku atau agama. Dengan adanya keragaman, di satu sisi dapat memberikan keuntungan dan bisa membawa kemajuan, namun di sisi lain dapat menimbulkan konflik jika dalam keragaman muncul sikap seliang menghina, tidak saling menghormati dan menghargai. Pluralitas merupakan suatu sunatullah dan tidak bisa dihindari. Dalam al Quran juga dijelaskan prinsip-prinsip pluralitas, di antaranya adalah pengakuan terhadap keberadaan agama lain (Q.S An Nahlu: 93), anjuran saling menghormati antar pemeluk agama (Q.S Al An'am: 108), anjuran berlomba-lomba untuk berbuat kebajikan (Q.S al Baqarah: 229), tidak memaksakan keyakinan kepada orang lain (Q.S al Baqarah: 256).

Pelaksanaan kenduri nikah di desa Barumanis juga mencerminkan nilai-nilai pluralisme, yaitu adanya kesadaran masyarakat akan kemajemukan. Kesadaran adanya kemajemukan tersebut diwujudkan dalam sikap saling menghargai, menghormati dan saling membantu dalam pelaksanaan tradisi kenduri nikah walaupun berbeda suku dan budaya (Sumarno, Komunikasi Pribadi, 2019). Di sisi lain, sikap plural juga tunjukkan masyarakat yang berbeda agama dan keyakinan. Masyarakat tetap menghormati, menghargai dan tidak mengganggu. Dalam bentuk kegiatan sosial kemasyarakatan terkait dengan kenduri nikah, warga yang berbeda agama dan keyakinan juga ikut serta dalam menghadiri undangan.

Kesadaran individual adanya keragaman dan diwujudkan dalam sikap saling menghargai, menghormati dan saling membantu, sangat penting untuk dilakukan guna menciptakan kerukunan dalam masyarakat mutikultural. Kenyataan pluralis masyarakat Indonesia pada umumnya dan masyarakat desa Barumanis khususnya, harus diikuti adanya kesadaran individual akan keragaman. Kesadaran individual akan terbentuk jika ada kesepakatan-kesepakatan sosial tanpa menghilangkan jati diri dan karakteristik masing-masing. Ada beberapa prinsip dalam masyarakat, agar keberagaman 
tidak menimbulkan konflik, yaitu tidak boleh saling memaksakan keyakinan, memberi kebebasan orang yang berbeda agama dan keyakinan untuk melaksanakan ibadah sesuai dengan agama dan keyakinannya, harus ada sikap saling menghargai dan menghormati (Abidin, A. A, 2018).

Menurut Ismail, F, (2016), untuk menciptakan kerukunan antar umat beragama, maka pluralisme harus diwujudkan dalam bentuk toleransi, yaitu sikap saling menghargai dan saling menghormati. Selain itu, untuk menjaga agar kerukunan tetap terjaga, maka sikap setuju dalam perbedaan atau agree in disagreement terhadap agama atau kepercayaan lain perlu dikembangkan. Hal senda juga dikemukakan oleh Hasanah, A, (2018), ada nilai etik inti yang harus dimiliki dan dikembangkan oleh setiap individu agar muncul sikap pluralistik, yaitu kepedulian, rasa hormat, keadilan, tanggung jawab dan kejujuran. Jika nilai etika inti ini sudah dimiliki oleh setiap anggota masyarakat, maka akan terbentuk karakter individu yang menghargai perbedaan dan sikap toleransi.

\section{PENUTUP}

$\begin{array}{cr}\text { Nilai-nilai } & \text { pendidikan } \\ \text { multikultural } & \text { mampu menjadi }\end{array}$ kesatuan masyarakat desa Barumanis, sehingga terbentuk kehidupan yang rukun dan damai dalam perbedaan suku, budaya, agama dan aliran kepercayaan. Nilai-nilai pendidikan Islam multikultural yang diimplementasikan dalam tradisi kenduri nikah tersebut adalah ; pertama, nilai demokratis, yang mencakup adanya kebebasan berkumpul dan mengemukakan pendapat, adanya kepatuhan terhadap tata kerama, adanya semangat kerja sama, adanya kesetaraan dan persamaan hak, adanya rotasi kepemimpinan dan sikap toleransi dalam perbedaan. Kedua, nilai humanistik, yang meliputi adanya saling menghormati, menghargai, kerja sama dan saling membantu antar sesama dalam keragaman. Ketiga, nilai pluralistik, mencakup adanya kesadaran masyarakat tentang adanya keragaman dalam perbedaan. Kesadaran ini menimbulkan sikap kepedulian, tanggung jawab dan hidup rukun dalam perbedaan.
Melalui tulisan ini, saya ucapkan terima kasih yang sebesar-besarnya kepada pimpinan redaksi beserta tim, Jurnal Edukasi: Jurnal Penelitian Pendidikan dan Keagamaan Kementerian Agama Republik Indonesia. Ucapan terima kasih juga saya ucapkan kepada Rektor IAIN Curup, Bapak Nursolihin, Ph.D selaku reviewer penelitian ini yang telah memberikan bimbingan dan masukan untuk kesempurnaan penelitian ini. Selian itu, ucapan terima kasih juga penulis sampaikan kepada tokoh masyarakat, tokoh agama dan tokoh adat desa Barumanis yang telah memberikan data untuk menjawab masalah penelitian ini. Semoga semuanya dibalas oleh Allah dengan balasan yang berlipat ganda. Amiin.

\section{DAFTAR PUSTAKA}

Abidin, A. A. (2018). Pluralisme Agama dan Implementasi Pendidikan Multikultural dalam Mewujudkan Konsep Masyarakat Madani di Indonesia. Proceedings of Annual Conference for Muslim Scholars, Series 2, 937-948.

Abuddin Nata. (2016). Ilmu Pendidikan Islam. Kencana.

Adisusilo, S. (2013). Pembelajaran Nilai-nilai Karakter. Rajawali Press.

Ahsantudhoni, A. (2019). Paradigma Multikulturalisme dan Pengembangan Kurikulum PAI. MIYAH: Jurnal Studi Islam, 14(12), 1-13.

Al Munawwar, S. A. H. (2011). Aktualisasi Nilai-nilai Qurani dalam Sistem Pendidikan Islam. Ciputat Perss.

Alam, M. (2018). Studi Penerapan Pendidikan Agama Islam Berbasis Multikultural di Institut Agama Islam negeri (IAIN) Kerinci. Tadrib, 4(2), 319-334.

Aly, A. (2011). Pendidikan Islam Multikultural di Pesantren, Telaah terhadap Kurikulum Pondok Pesantren Modern Islam Assalaam Surakarta. Pustaka Pelajar.

Aly, A. (2017). Studi Deskriptif Tentang NilaiNilai Multikultural dalam Pendidikan di Pondok Pesantren Modern Islam Assalaam. Jurnal Ilmiah Pesantren, 1(1 Januari).

\section{UCAPAN TERIMAKASIH}


Amalia, R. (2016). Penerapan Konseling Eksistensial Humanistik Berbasis Nilai Budaya Minangkabau dalam Kesetaraan Gender untuk Meningkatkan Self Esteem Pada Remaja Putri. Jurnal Bimbingan dan Konseling Ar-Rahman, 2(2), 9-16.

Arifin, Z. (2011). Pendidikan MultikulturalReligius untuk Mewujudkan Karakter Peserta Didik yang Humanis-Religius. Jurnal Pendidikan Islam, 1(1), 89-103.

Azizah, L, \& Azhar, P. (2016). Islam di Tengah Masyarakat Multikultural Indonesia (Studi Atas Konsep Multikultural Abdul aziz Sachedina). TOLERANSI: Media Ilmiah Komunikasi Umat Beragama, 7(1), 70-88.

Baharun, H, \& Awwaliyah, R. (2017). Pendidikan Multikultural dalam Menanggulangi Narasi Islamisme di Indonesia. Jurnal Pendidikan Agama Islam (Journal of Islamic Education Studies), 5(2), 224-243.

Bastari. (2019). Wawancara dengan Bastari, 05 Oktober 2019.

Bukhori, I. (2018). Nilai-Nilai Pendidikan Multikultural dalam Mata Pelajaran Aswaja dan ke-NU-an Siswa SMP/MTs. At-Ta'lim: Jurnal Pendidikan, 4(1), 3556.

Dana, M. A. (2020). At-Tarbiyah Sebagai Konsep Pendidikan dalam Islam. INOVATIF: Jurnal Penelitian Pendidikan, Agama dan Kebudayaan, 6(1), 88-104.

Darajat, Z. (2012). Dasar-dasar Agama Islam. Bulan Bintang.

Departemen Pendidikan dan Kebudayaan. (2014). Kamus Besar Bahasa Indonesia. Balai Pustaka.

Elly.M, Setiadi, \& dkk. (2011). Ilmu Sosial Budaya Dasar. Kencana Persada Media.

H.A.R, Tilaar. (2012). Perubahan Sosial dan Pendidikan: Pengantar Pedagogik Transformatif untuk Indonesia. Grasindo.

Hasanah, A. (2018). Sprit Pluralisme Dalam Konstruktur Karakter Bangsa Indonesia (Sebuah Pendekatan Sosio-Historis Pada
Konsep Nation State). Al-Risalah, 11(01), 1-19.

Holilah, M. (2016). Kearifan ekologis budaya lokal masyarakat adat cigugur sebagai sumber belajar IPS. Jurnal Pendidikan Ilmu Sosial, 24(2), 163-178.

Irawan, I, \& Hermawan, D. (2019). Konseptual Model Pendidikan Demokratis Perspektif Pendidikan Islam. Ta'dib: Jurnal Pendidikan Islam, 8(2), 626-631.

Ismail, F. (2016). Islam, Pluralisme dan Kerukunan Hidup Antar Umat Beragama di Indonesia. UNISIA, 33, 58-68.

Jamhuri, M. (2018). Humanisme sebagai Nilai Pendekatan yang Efektif dalam Pembelajaran dan Bersikap, Perspektif M ultikulturalisme di Universitas Yudharta Pasuruan. AL MURABBI, 3(2), 317-334.

Kahija, Y. L. (2017). Penelitain Fenomenologi Jalan Memehami Pengalaman Hidup. Kasinus.

Kusniyati, H, \& Sitanggang, N. S. P. (2016). Aplikasi Edukasi Budaya Toba Samosir Berbasis Android. Jurnal Teknik Informatika, 9(1).

Machsun, T. (2017). Pembaruan Pendidikan Agama Islam di Madrasah. EL-BANAT: Jurnal Pemikiran dan Pendidikan Islam, 7(1), 151-165.

Maksum, A. (2015). Model Pendidikan Toleransi di Pesantren Modern dan Salaf. Jurnal Pendidikan Agama Islam: Journal of Islamic Education Studies, 3(1), 81-108.

Malla, H. A. B. (2017). Pembelajaran Pendidikan Agama Islam Berbasis Multikultural Humanistik dalam Membentuk Budaya Toleransi Peserta Didik di SMA Negeri Model Madani Palu, Sulawesi Tengah. INFERENSI: Jurnal Penelitian Sosial Keagamaan, 1191), 163-186.

Manser, H, \& Martin, H. (2011). Oxford Learner's Pocket Dictionary. Oxford University Perss. 
Masgnud. (2010). Pendidikan Multikultural: Pemikiran dan Upaya Implementasinya. Idea Press.

Moleong, L. J. (2014). Metode Penelitian Kualitatif. Remaja Rosdakarya.

Mulyana, R. (2011). Mengartikulasikan Pendidikan Nilai. Alfabeta.

Nazir, Moh. (2015). Metode Penelitian. Ghalia Indonesia.

Nur, M. (2019). Nilai-nilai Pendidikan Agama Islam dalam Konsep Pendidikan Multikultural. el-Buhuth: Borneo Journal of Islamic Studies, 2(1), 1-7.

Pettalongi, S. S. (2013). Islam dan Pendidikan Humanis dalam Resolusi Konflik Sosial. Cakrawala Pendidikan, 2, 95-142.

Pransiska, T. (2020). Model Pendidikan Multikultural di Panti Asuhan Mizan Amanah Yogyakarta: Prototip Pendidikan Ramah Anak. EDUKASI: Jurnal Penelitian Pendidikan Agama dan Keagamaan, 18(1), 70-83.

Prasisko, Y. G. (2019). Bemokrasi Indonesia dalam Masyarakat Multikultural. Waskita: Jurnal Pendidikan Nilai dan Pembangunan Karakter, 3(1), 1-12.

Pulungan, K. S. (2019). Hukum Memberi Karangan Bunga pada Walimatul Ur's (Studi terhadap Pandangan Majelis Ulama Indonesia (MUI) Kab. Rokan Hulu). HUKUMAH: Jurnal Hukum Islam, 2(2), 51-69.

Tim Penyusun. (2018). Profil desa Barumanis Kecamatan Bermanu Ulu Kabupaten Rejang LebongProvinsi Bengkulu

Ramayulis. (2016). Ilmu Pendidikan Islam. Kalam Mulia.

Rodin, R. (2013). Tradisi Tahlilan dan Yasinan. IBDA: Jurnal Kajian Islam dan Budaya, 11(1), 76-87.

Rofiq, A, \& Muqfy, H. (2019). ., \&. (2019). Analisis Pendidikan Islam Multikultural sebagai Pemersatu Bangsa. , 1(1), 134147. MANAGERE: Indonesian Journal of Educational Management, 1(1), 134147.
Rois, A. (2013). Pendidikan Islam multikultural: Telaah Pemikiran Muhammad Amin Abdullah. Epistemé: Jurnal Pengembangan Ilmu Keislaman, 8(2), 301-322.

Sali, M. (2019). Wawncara cengan M.Sali, 03 Oktober.

Saring. (2019). Wawancara dengan Saring, 03 Oktpber.

Saepudin, J. (2019). Pendidikan Agama Islam Pada Sekolah Berbasis Pesantren: Studi Kasus Pada SMP Al Muttaqin Kota Tasikmalaya. Edukasi, 17(2), 294537.

Setiawan, A, \& Sulistiani, I. R. (2019). Pendidikan Nilai, Budaya Dan Karakter Dalam Pembelajaran Matematika Dasar Pada SD/MI. Elementerls: Jurnal Ilmiah Pendidikan Dasar Islam, 1(1), 41-56.

Shihab, M. Q. (2013). Tafsir Al Quran Al Karim: tafsir atas Surat-surat Pendek Berdasarkan Urutan Turunnya Wahyu. Pustaka Hidayah.

Siswayanti, N. (2018). Mengenal Masjid Nahdliyin dalam Peranan Masjid Jami Kajen. Jurnal Bimas Islam, 11(2), 277300.

Suacana, I. W. G. (2015). Nilai-nilai dan Parameter Demokrasi dalam Kehidupan Masyarakat Bali. Jurnal Kajian Bali (Journal of Bali Studies), 5(1).

Sudirman, M. (2019). Tradisi Mappasikarawa dalam Pernikahan Adat Bugis. Ash Shahabah, 5(1), 9-100.

Sugiono. (2018). Metode Penelitian Pendidikan: Pendekatan Kuantitatif, Kualitatig dan $R \& D$. Alfabeta.

Suhendroyono, S, \& Novitasari, R. (2016). Pengelolaan Wisata Alam Watu Payung sebagai Ikon Wisata Berbasis Budaya di Gunungkidul Yogyakarta. Kepariwisataan: Jurnal Ilmiah, 10(1).

Sukardi, J. S, Hanum, F, Dwiningrum, S. I. A, \& Efianingrum, A. (2019). Cultural Understanding of the Students for Multicultural Education in the University. KnE Social Sciences, 358366. 
Sumarno. (2019). Wawancara dengan Sumarno, 04 Oktober.

Supriadi, S. (2017). Pendidikan Islam Multikultural (Tantangan dan Relevansinya di Indonesia). ITTIHAD, 13(23), 1-14.

Suripto, S. (2018). Revitalisasi Islamic Education Epistemology. EDUKASI: Jurnal Pendidikan Islam, 6(2), 125-136.

Suryana, Yaya, \& Rusdiana H. A. (2015). Pendidikan Multikultural, Konsep, Prinsip dan Implementasi. Pustaka Setia.

Suyono. (2019). Wawancara dengan Suyono, 06 Oktober.

Tafsir, A. (2011). Ilmu pendidikan dalam perspektif Islam. Remaja Rosdakarya.

Thohiri, M. K. (2018). Tradisi Pesantren Salafiyah dan Modern dalam Konteks Deradikalisasi. In Proceedings of Annual Conference for Muslim Scholars, Series 2, 629-642.
Tumisem. (2019). Wawancara dengan Tumisem, 06 Oktober.

Warsito. (2019). Wawancara dengan Warsito, 07 Oktober.

Wibowo, A. M. (2018). Multikulturalisme Peserta Didik Muslim di Yogyakarta. Edukasi, 16(1), 294617.

Wojciechowska, M. (2016). Reviews: Piotr Sztompka,"Social capital. Interpersonal space theory", Cracovian publisher Znak, Kraków 2016, pp. 384. Political Preferences, (13), 184-186. 